\title{
Effectiveness of Beet Root Juice on Reduction of Blood Pressure among People with Hypertension at Sothupakkam, Kanchipuram District
}

\author{
Vaishnavi.D
}

Assistant Professor, Dept of Community Health Nursing, Mailam, Tamil Nadu

\section{ABSTRACT}

Aim: Effectiveness of beet root juice on reduction of blood pressure among people with hypertension at Sothupakkam, Kanchipuram district

Objectives: (i) to assess the level of blood pressure among people with hypertension residing at Sothupakkam. (ii) to evaluate the effectiveness of beetroot juice on reduction of blood pressure among people with hypertension (iii) to find out the association between effectiveness of beetroot juice on reduction of blood pressure with the selected demographic variables.

Methodology: Researcher adopted the quantitative research approach, one group pre test and post test design, study samples with the age group 25-65 years old for 60 samples at Sothupakkam Kanchipuram district using purposive sampling technique

Results: The findings of the study was pre and post systolic mean difference 30.66 with the standard deviation 10.39 and applying paired ' $\mathrm{t}$ ' test value 22.8 and pre and post diastolic mean difference 17.33 with standard deviation 10.22 and applying the paired ' $t$ ' test value 13.1 since the calculated value was greater than the table value at 0.05 level of significance. Hence it was significant improvement in reduction of blood pressure among people with hypertension. It has shown that the consumption of beet root juice was effective

Conclusion: The present study was conducted in Sothupakkam village with the sample size 60 people with hypertension and they had been administered with the beet root juice on reduction of blood pressure which showed the remarkable changes in the health status of the susceptible of people with hypertension and they had give the feedback regarding the effectiveness of the natural home remedy.

Keywords: Beet root juice, hypertension, high blood pressure

\section{INTRODUCTION}

Hypertension is high blood pressure; also known as "silent killer" is a very common condition that can be lead to or complicate many health problems. About $31 \%$ people who had pressure exceeding $140 / 90 \mathrm{mmHg}$ were unaware of their elevated blood pressure.

Once identified elevated blood pressure, persistent for a lifelong period. There are number of reasons why people have hypertension, some of them are inherited such as being made or having a family history of elderly heart attacks or stroke. Other risks may be partly inherited such as predisposition to hypertension or obesity

World health organization (2015) Over all, approximately $20 \%$ of the world's adult are estimated to have hypertension, when hypertension is defined as blood pressure excess of $140 / 90 \mathrm{mmHg}$. The prevalence dramatically increases in patients older than 60 years; in many countries, $50 \%$ of individuals in this age group have hypertension, contributing to more than 7.1 million per year

Indian council of medical and research study in 2014 involving 5537 individuals (3050 residents and 2487 rural residents) demonstrated $25 \%$ and $29 \%$ 
prevalence of hypertension $(140 / 90 \mathrm{mmHg})$ among males and females respectively in urban Delhi and $13 \%$ and $10 \%$ in rural Haryana.

Recent studies using revised criteria (BP>or 140 and 90mmHg) have shown a prevalence of hypertension among urban adults. There are 31.5 million hypertensives in rural and 34 million in urban populations. A total $70 \%$ of these would be the stage I hypertension (systolic blood pressure 140$159 \mathrm{mmHg}$ and diastolic blood pressure 90$100 \mathrm{mmHg}$ ). In Tamil Nadu the prevalence of hypertension ranges from $20-40 \%$ in urban adults and $12-17 \%$ among rural adults. The number of people with hypertension is projected to increase from 118 million in 2000 to 214 million in 2025 , with nearly equal numbers of men and women.

A survey of 26,000 adults in south India showed a hypertension prevalence of $20 \%$ (men $23 \%$ and women $17 \%$ ) but $67 \%$ of those with hypertension was unaware of their diagnosis. Majority of hypertensive subjects still remain undetected and the control of hypertension is also inadequate. This calls for urgent prevention and control measures for hypertension.

\section{Prevalence of Hypertension in South East Asian Region}

Prevalence of hypertension is increasing in many countries in the region. In India, raised blood pressure was increased from $5 \%$ in the 1960 s to $12 \%$ in 1990 s, and more than $30 \%$ in 2014. In Indonesia, the percentage of adult population with raised blood pressure was increased from 8\% in 1995 to $32 \%$ in 2014. In Myanmar, the ministry of health reported the increase in the high blood pressure.

\section{Prevalence of Hypertension in India}

Indian Council of Medical and Research: study in 2014 involving 5537 individuals (3050 residents and 2487 rural residents) demonstrated $25 \%$ and $29 \%$ prevalence of hypertension $(140 / 90 \mathrm{mmHg})$ among male and female respectively in urban Delhi and 13\% and 10\% in rural
Haryana. Hypertension prevalence study was carried out $(160 / 95 \mathrm{mmHg})$ in rural Kerala during 2001 in the 20 plus age group and the prevalence was found to be $18 \%$. Later studies in Kerala carried out among 30-64years age group in 1998 and 55\% among 40-60 age group during 2000 .

\section{Prevalence of Hypertension in Tamilnadu} International journal of public health reported at $21.4 \%$ of hypertension prevalence in about 10,500 people aged (25$64)$ in 11 villages in the state. Prevalence was nearly the same in both sexes. When it comes to hypertension prevalence, rural India is not far behind its urban counterpart and the earlier studies had documented $16 \%$ prevalence in rural areas and studies carried out later in other states had reported $20 \%$ of prevalence. Prevalence of hypertension in urban areas is $22-30 \%$. The latest study gains importance as there is very big data on prevalence of hypertension in rural Tamil Nadu. In the rural population a large percentage of people are ignorant about the condition and it is indeed a major cause for concern. "About $75 \%$ people ignorant of their condition in rural areas"

\section{Statement of the Problem}

Effectiveness of Beet Root Juice on Reduction of Blood Pressure among People with Hypertension at Sothupakkam, Kanchipuram district

\section{Objectives of the Study}

* to assess the level of blood pressure among people with hypertension residing at Sothupakkam.

* to evaluate the effectiveness of beetroot juice on reduction of blood pressure among people with hypertension

* to find out the association between effectiveness of beetroot juice on reduction of blood pressure with the selected demographic variables.

\section{HYPOTHESIS}

H1: There will be post test level of blood pressure will be significantly lower than the pretest level of blood pressure. 
$\mathrm{H} 2$ : There will be a significant association between the pretest level of blood pressure and selected demographic variables.

\section{MATERIAL AND METHODS}

Researcher adopted the quantitative research approach, one group pre test and post test design, study samples with the age group 25-65 years old for 60 samples at Sothupakkam Kanchipuram district using purposive sampling technique

\section{RESULTS AND DISCUSSION}

Table 1.1 shows the health status of people with hypertension on reduction of blood pressure before and after consumption of beet root juice. On the pre test, no normal hypertension persons, $15(25 \%)$ were pre hypertension persons, $45(75 \%)$ were hypertensive persons. During the post test, $40(66.7 \%)$ were normal hypertension persons, 20 (33.3\%) were pre hypertension persons, and no hypertension persons was reported.

Table 1.1 Comparison of frequency and percentage distribution of the presence of people with hypertension before and after giving the beet root juice on reduction of blood pressure

\begin{tabular}{|c|c|c|c|c|c|c|c|}
\hline \multirow{2}{*}{$\begin{array}{c}\text { S. } \\
\text { No }\end{array}$} & $\begin{array}{l}\text { Health } \\
\text { Status }\end{array}$ & \multicolumn{2}{|c|}{ Normal } & \multicolumn{2}{c|}{$\begin{array}{c}\text { Pre } \\
\text { hypertension }\end{array}$} & \multicolumn{2}{c|}{ Hypertension } \\
\cline { 3 - 8 } & & Freq & $\%$ & Freq & $\%$ & Freq & $\%$ \\
\hline 1. & Pre test & 0 & 0 & 15 & $25 \%$ & 45 & $75 \%$ \\
\hline 2. & Posttest & 40 & 66.7 & 20 & 33.3 & 0 & 0 \\
\hline
\end{tabular}

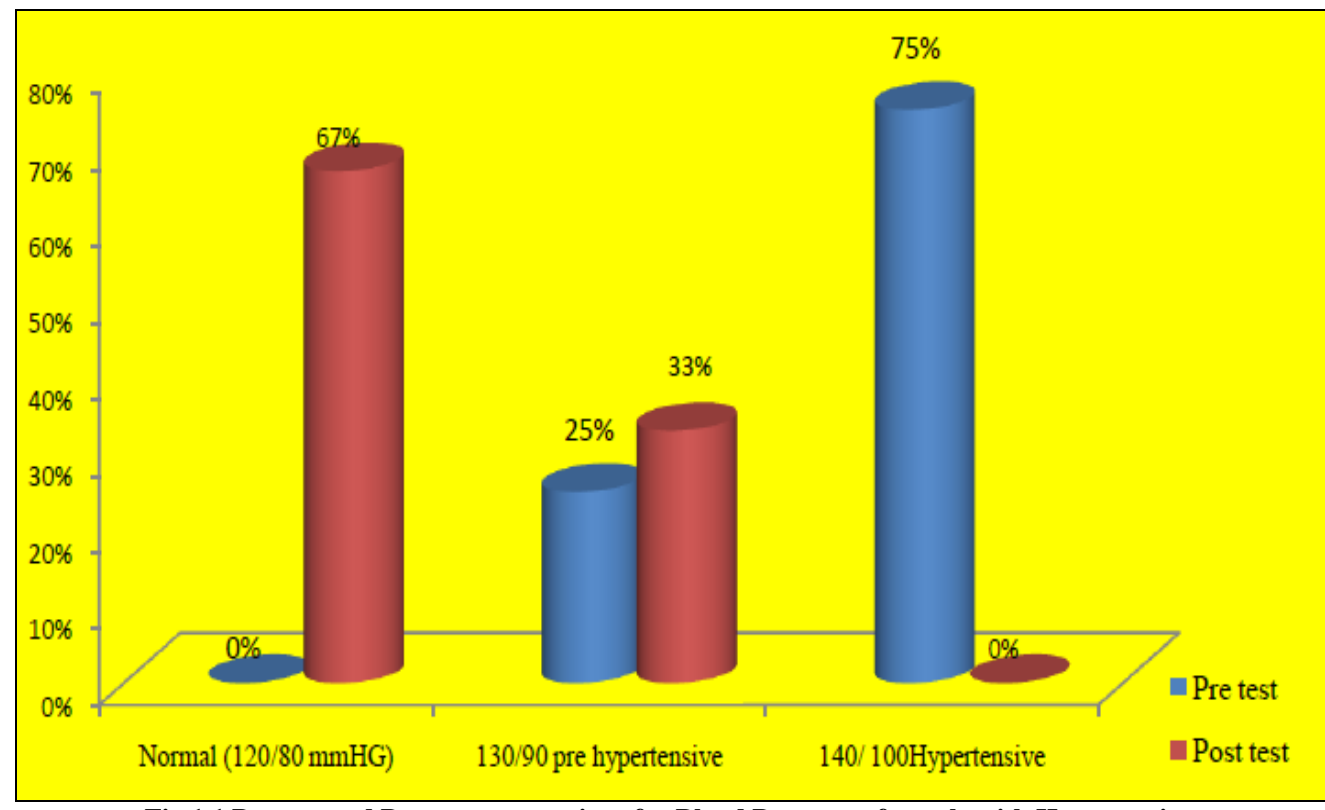

Fig 1.1 Pre test and Post test comparison for Blood Pressure of people with Hypertension

Table1.2 Depicts the Improvement Score of the Reduction of Blood Pressure among the People with Hypertension before and After Consumption of Beet Root Juice

\begin{tabular}{|c|l|c|c|c|}
\hline $\begin{array}{c}\text { S. } \\
\text { no }\end{array}$ & $\begin{array}{c}\text { Blood } \\
\text { Pressure }\end{array}$ & $\begin{array}{c}\text { Mean } \\
\text { Difference }\end{array}$ & $\begin{array}{c}\text { Standard } \\
\text { Deviation }\end{array}$ & $\begin{array}{c}\text { 't' } \\
\text { value }\end{array}$ \\
\hline 1. & $\begin{array}{l}\text { Pre systolic } \\
\text { Post systolic }\end{array}$ & 30.66 & 10.39 & 22.8 \\
\hline 2. & $\begin{array}{l}\text { Pre diastolic } \\
\text { Post diastolic }\end{array}$ & 17.33 & 10.22 & 13.1 \\
\hline
\end{tabular}

This table shows the improvement in the mean score of pre and post systolic blood pressure mean difference 30.66 with the standard deviation 10.39 and applying the paired ' $t$ ' test value 22.8 and pre and post diastolic mean difference 17.33 with standard deviation 10.22 and applying the paired ' $t$ ' test value 13.1 since the calculated value was greater than the table value at 0.05 level of significance. Hence it was statistically proved that there was highly significant improvement in reduction of blood pressure among the people with Hypertension. It has shown that the consumption of beet root juice was effective 
Vaishnavi.D. Effectiveness of beet root juice on reduction of blood pressure among people with hypertension at Sothupakkam, Kanchipuram district

Association between the Selected Demographic variables with the Effectiveness of Beet Root Juice on Reduction of Blood Pressure

\begin{tabular}{|c|c|c|c|c|c|c|c|}
\hline \multirow[t]{3}{*}{ S. NO. } & \multirow[t]{3}{*}{ Demographic variables } & \multicolumn{4}{|c|}{ post test } & \multirow{3}{*}{$\begin{array}{l}\text { chi square } \\
\text { p value }\end{array}$} & \multirow{2}{*}{$\begin{array}{c}\mathbf{p} \\
\text { value }\end{array}$} \\
\hline & & \multicolumn{2}{|c|}{ Normal } & \multicolumn{2}{|c|}{ Pre hypertension } & & \\
\hline & & No & $\%$ & No & $\%$ & & \\
\hline \multirow[t]{5}{*}{1.} & Age & & & & & & \\
\hline & a)25-35 years & 6 & 10.0 & 1 & 1.7 & 2.248 & 0.52 \\
\hline & b) $36-45$ years & 7 & 11.7 & 2 & 3.3 & & \\
\hline & c) $46-55$ years & 12 & 20.0 & 7 & 11.7 & & \\
\hline & d)Above 55 Years & 15 & 25.0 & 10 & 16.7 & & \\
\hline \multirow[t]{3}{*}{2.} & Gender & & & & & & \\
\hline & a)Male & 14 & 23.3 & 6 & 10.0 & 0.150 & 0.69 \\
\hline & b)Female & 16 & 43.3 & 14 & 23.3 & & \\
\hline \multirow[t]{5}{*}{3.} & Religion & & & & & & \\
\hline & a)Hindu & 34 & 60.0 & 14 & 23.3 & $5.640 *$ & 0.04 \\
\hline & b)Christian & 4 & 6.7 & 4 & 6.7 & & \\
\hline & c)Muslim & 0 & 0.0 & 2 & 3.3 & & \\
\hline & d)Others & 0 & 0.0 & 0 & 0 & & \\
\hline 4. & Education & & & & & & \\
\hline & a)Illiterate & 9 & 15.0 & 9 & 15.0 & 4.786 & 0.31 \\
\hline & b)Primary & 12 & 20.0 & 4 & 6.7 & & \\
\hline & c)High School & 9 & 15.0 & 5 & 8.3 & & \\
\hline & d) $\mathrm{HSC}$ & 2 & 3.3 & 1 & 1.7 & & \\
\hline & e)Graduate and Above & 8 & 13.3 & 1 & 1.7 & & \\
\hline 5. & Occupation & & & & & & \\
\hline & a)Coolie & 7 & 11.7 & 7 & 11.7 & 5.475 & 0.24 \\
\hline & b)Non Professional & 3 & 5.0 & 1 & 1.7 & & \\
\hline & c)Professional & 7 & 11.7 & 0 & 0.0 & & \\
\hline & d)Business & 3 & 5.0 & 2 & 3.3 & & \\
\hline & e)Unemployed & 20 & 33.3 & 10 & 16.7 & & \\
\hline 6. & Type of work & & & & & & \\
\hline & a)Sedentary & 25 & 41.7 & 11 & 18.3 & 4.148 & 0.12 \\
\hline & b)Moderate & 15 & 25.0 & 7 & 11.7 & & \\
\hline & c)Heavy & 0 & 0.0 & 2 & 3.3 & & \\
\hline 7. & Income & & & & & & \\
\hline & a)Up to Rs 5000 & 23 & 38.3 & 12 & 20.0 & 2.952 & 0.39 \\
\hline & b)Rs $5001-10000$ & 7 & 11.7 & 5 & 8.3 & & \\
\hline & c)Rs $10001-15000$ & 5 & 8.3 & 3 & 5.0 & & \\
\hline & d)Above Rs 15000 & 5 & 8.3 & 0 & 0.0 & & \\
\hline 8. & Marital status & & & & & & \\
\hline & a)Married & 24 & 40.0 & 15 & 25.0 & 3.257 & 0.35 \\
\hline & b)Unmarried & 4 & 6.7 & 0 & 0.0 & & \\
\hline & c)Divorced/Separated)Widow & 5 & 8.3 & 1 & 1.7 & & \\
\hline & & 7 & 11.7 & 4 & 6.7 & & \\
\hline 9. & Type of family & & & & & & \\
\hline & a)Nuclear family & 25 & 41.7 & 13 & 21.7 & 0.036 & 0.85 \\
\hline & b)Joint family & 15 & 25.0 & 7 & 11.7 & & \\
\hline & c)Broken Family & 0 & 0.0 & 0 & 0.0 & & \\
\hline 10. & Dietary pattern & & & & & & \\
\hline & a)Vegetarian & 6 & 10.0 & 3 & 5.0 & 0.000 & \\
\hline & b)Non Vegetarian & 34 & 56.7 & 17 & 28.3 & & 1.00 \\
\hline 11. & Consumption of non Vegetarian & & & & & & \\
\hline & a)Daily & 4 & 6.7 & 4 & 6.7 & 1.650 & 0.80 \\
\hline & b)Weekly & 13 & 21.7 & 7 & 11.7 & & \\
\hline & c)Monthly & 15 & 25.0 & 5 & 8.3 & & \\
\hline & d)Occasionally & 2 & 3.3 & 1 & 1.7 & & \\
\hline & e)Never & 6 & 10.0 & 3 & 5.0 & & \\
\hline 12. & Personal Habits & & & & & & \\
\hline & a)Alcoholism & 2 & 3.3 & 0 & 0.0 & 1.360 & 0.71 \\
\hline & b)Betel chewing & 5 & 8.3 & 3 & 5.0 & & \\
\hline & c)Others & 4 & 6.7 & 3 & 5.0 & & \\
\hline & d)No bad habits & 29 & 48.3 & 14 & 23.3 & & \\
\hline 13. & Habitual Pattern & & & & & & \\
\hline & a)Daily & 4 & 6.7 & 3 & 5.0 & 1.904 & 0.75 \\
\hline & b)Weekly & 1 & 1.7 & 0 & 0.0 & & \\
\hline & c)Monthly & 5 & 8.3 & 2 & 3.3 & & \\
\hline & d) Occasionally & 2 & 3.3 & 0 & 0.0 & & \\
\hline & e)Never & 28 & 46.7 & 15 & 25.0 & & \\
\hline 14. & Blood Pressure & & & & & & \\
\hline & a) $<120 / 80 \mathrm{mmHg}$ & 0 & 0.0 & 0 & 0.0 & 0.072 & 0.78 \\
\hline & b) $120 / 80-140 / 90 \mathrm{mmHg}$ & 5 & 8.3 & 3 & 5.0 & & \\
\hline & c)Above $140 \mathrm{mmHg}$ & 35 & 58.3 & 17 & 28.3 & & \\
\hline
\end{tabular}


Vaishnavi.D. Effectiveness of beet root juice on reduction of blood pressure among people with hypertension at Sothupakkam, Kanchipuram district

\begin{tabular}{|c|c|c|c|c|c|c|c|}
\hline \multicolumn{8}{|c|}{ Table no 1. Continued... } \\
\hline \multirow[t]{5}{*}{15.} & Family history of Disease & & & & & & \\
\hline & a)Respiratory disease & 8 & 13.3 & 3 & 5 & \multirow[t]{4}{*}{0.389} & \multirow[t]{4}{*}{0.942} \\
\hline & b) $\mathrm{HT}^{1}$ & 17 & 28.3 & 8 & 13.3 & & \\
\hline & c)Heart diseases & 5 & 8.3 & 3 & 5.0 & & \\
\hline & d)Others & 10 & 16.7 & 6 & 10.0 & & \\
\hline \multirow[t]{5}{*}{16.} & Hyper tension since & & & & & & \\
\hline & a)Less than 1 year & 31 & 51.7 & 15 & 25.0 & \multirow[t]{4}{*}{2.511} & \multirow[t]{4}{*}{0.473} \\
\hline & b) $1-3$ years & 6 & 10.0 & 3 & 5.0 & & \\
\hline & c) $3-5$ years & 1 & 1.7 & 2 & 3.3 & & \\
\hline & d)More than 5 years & 2 & 3.3 & 0 & 0.0 & & \\
\hline \multirow[t]{5}{*}{17.} & On treatment & & & & & & \\
\hline & a)Less than 1 year & 19 & 31.7 & 10 & 16.7 & \multirow[t]{4}{*}{0.717} & \multirow[t]{4}{*}{0.869} \\
\hline & b) $1-3$ years & 8 & 13.3 & 4 & 6.7 & & \\
\hline & c) $3-5$ years & 6 & 10.0 & 4 & 6.7 & & \\
\hline & d)Above 5 years & 7 & 11.7 & 2 & 3.3 & & \\
\hline \multirow[t]{5}{*}{18.} & Regular Activities & & & & & & \\
\hline & a)Yoga & 19 & 31.7 & 8 & 15.0 & \multirow{4}{*}{1.232} & \multirow{4}{*}{0.74} \\
\hline & b)Meditation & 13 & 21.7 & 3 & 13.3 & & \\
\hline & c)Physical Exercises & 6 & 10.0 & 3 & 5.0 & & \\
\hline & d)None & 2 & 3.3 & 0 & 0.0 & & \\
\hline \multirow[t]{4}{*}{19.} & Regular activities & & & & & & \\
\hline & Regular & 23 & 38.3 & 7 & 11.7 & \multirow[t]{3}{*}{3.574} & \multirow[t]{3}{*}{0.16} \\
\hline & Sometimes & 16 & 26.7 & 13 & 21.7 & & \\
\hline & Irregular & 1 & 1.7 & 0 & 0.0 & & \\
\hline \multirow[t]{5}{*}{20.} & Presence of co- morbidities & & & & & & \\
\hline & a)DM & 13 & 21.7 & 6 & 10.0 & \multirow{4}{*}{2.445} & \multirow{4}{*}{0.48} \\
\hline & b)Cardiac disorder & 3 & 5.0 & 1 & 1.7 & & \\
\hline & c)Others & 7 & 11.7 & 7 & 10.0 & & \\
\hline & d)None & 17 & 28.3 & 6 & 1.7 & & \\
\hline
\end{tabular}

In these table shows that there was significant association between religion and the effectiveness of beet root juice on reduction of blood pressure and other selected demographic variables showed no significant association with the effectiveness of beet root juice on reduction of blood pressure

\section{DISCUSSION}

The first objective was to assess the level of blood pressure among people with hypertension residing at Sothupakkam.

On the pretest mean value of pre systolic blood pressure was 140.66 , with the standard deviation 7.24 and pre diastolic blood pressure mean was 87.66, with the standard deviation 4.99, post systolic blood pressure mean was 109.50, with the standard deviation 6.99 and, post diastolic blood pressure mean was 70.33 with the standard deviation 8.22.

Second objectives evaluate the effectiveness of beetroot juice on reduction of blood pressure among people with hypertension.

During the pre test score determinants, no normal hypertension, $15(25 \%)$ were pre hypertension, $45(75 \%)$ were hypertensive persons after administering the beet root juice was given for 21 days the post test score determines, that $40(66.7 \%)$ were normal hypertension persons, 20(33.3\%) were pre hypertension persons, and no hypertension persons were reported.

Hence it has been agreed that the post test level of blood pressure will be significantly lower than the pre test level of blood pressure

The third objective was to find out the association between effectiveness of beetroot juice on reduction of blood pressure with the selected demographic variables.

There was a significant relationship between religion and the effectiveness of beet root juice on reduction of blood pressure, and other selected demographic variables showed no significant association with the effectiveness of beet root juice on reduction of blood pressure

\section{CONCLUSION}

The statistical analysis shown that the mean and standard deviation of pre systolic mean was 140.66 with the standard deviation 7.24, pre diastolic mean was 87.66 
with the standard deviation 4.99 , and post systolic mean was 109.66 with the standard deviation 6.99 and post diastolic mean was 70.33 with standard deviation of 8.27 and, ' $t$ ' test value was 22.8 and 13.1 with the $\mathrm{P}<0.001$ shows highly significant, and there was significant association between the selected demographic variables such as religion and the effectiveness of beet root juice on reduction of blood pressure, finally it was concluded that there was a significant improvement in the health status of the people with hypertension.

conducted in Sothupakkam village with the sample size 60 people with hypertension and they had been administered with the beet root juice on reduction of blood pressure which showed the remarkable changes in the health status of the susceptible of people with hypertension and they had give the feedback regarding the effectiveness of the natural home remedy.

\section{Acknowledgement: None}

\section{Conflict of Interest: None}

\section{Source of Funding: None}

Ethical Approval: Approved

\section{REFERENCES}

1. Basvanthappa B.T, (2016), "Community Health Nursing", $2^{\text {nd }}$ edition, Jaypee Publishers.

2. Barbara C. Long,(2016), "Medical Surgical Nursing", $3^{\text {rd }}$ edition, Mosby publications

3. Brunner \& Suddarth's, (2014), "Textbook of Medical Surgical Nursing", $6^{\text {th }}$ edition, Smeltzer publication
4. Clement, (2013), "Manual of Community Health Nursing", $3^{\text {rd }}$ edition, Jaypee Publications.

5. Demetrius James,(2013), "Public \& Community Health Nursing Practice", $1^{\text {st }}$ edition, Lippincott Publications

6. Mahajan B.K. (2013), "Methods of Biostatistics", $3{ }^{\text {rd }}$ edition Jaypee Publishers.

7. Marcia Stanhope (2015), "Community and Public Health Nursing", $4^{\text {th }}$ edition, Mosby Publications.

8. Mary Saunders (2014), "Community Health Care Nursing", $4^{\text {th }}$ edition, Mosby Publications.

9. Park's (2015), “Text book of Preventive and Social Medicine", 24 $4^{\text {th }}$ edition, Banarsidas Bhanot Publishers.

10. Phipps, (2014), "Medical Surgical Nursing", $6^{\text {th }}$ edition, Lippincott Company.

11. Polit. F, Beck, (2015), "Nursing Research", $8^{\text {th }}$ edition, Lippincott Publications.

12. Sunitha (2015), "Text book of Community Health Nursing", $1^{\text {st }}$ edition, Modern Publications.

13. Vijay.E (2013), "Community Medicine", $1^{\text {st }}$ edition, Beacon Zen Publishers.

14. Watson (2014), "Medical Surgical Nursing", $4^{\text {th }}$ edition, published by W.B. Saunders Company.

15. Wesley L. Ruby (2015), "nursing Theories and Models", $2^{\text {nd }}$ edition, Pennsylvania Spring House

How to cite this article: Vaishnavi.D. Effectiveness of beet root juice on reduction of blood pressure among people with hypertension at Sothupakkam, Kanchipuram district. International Journal of Science \& Healthcare Research. 2021; 6(4): 93-98. DOI: https:// doi.org/10.52403/ijshr.20211015 